\title{
Variations in Tribology Factors of SM45C by UNSM Modification
}

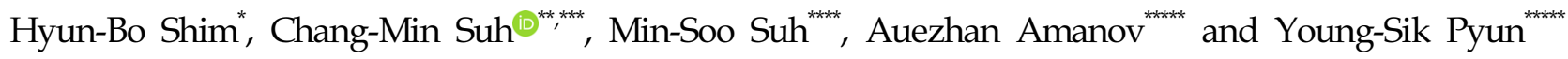 \\ "School of Mechanical Engineering, Yeungnam University, Kyungsan, Korea \\ "School of Mechanical Engineering, Kyungpook Nat'l University, Daegu, Korea \\ DMI Senior Fellow, Daegu, Korea \\ ***at Korea Institute of Energy Research, Daejun, Korea \\ Department of Mechanical Engineering, Sun Moon University, Asan, Korea
}

\section{$\mathrm{SM} 45 \mathrm{C}$ 재의 UNSM 처리에 의한 트라이볼러지 특성 변화}

\author{
심현보 · 서창민( ${ }^{* * * * k *} \cdot$ 서민수 \\ *영남대학교 기계공학부 \\ "경북대학교 기계공학부 \\ 대구기계부품연구원 자문위원 \\ * 한국에너지연구원 \\ 선문대학교 기계공학부
}

KEY WORDS: Tibology 트라이볼러지, Press die 프레스 금형, SM45C, Surface hardness 표면경도, Ultrasonic nanocrystal surface modification 초음파나노표면개질, Friction coefficient 마찰계수

\begin{abstract}
The following results were obtained from a series of studies to accumulate data to reduce the coefficient of friction for press dies by performing tribological tests before and after the UNSM treatment of SM45C. The UNSM-treated material had a nano-size surface texture, high surface hardness, and large and deep compressive residual stress formation. Even when the load was doubled, the small amount of abrasion, small weight of the abrasion, and width and depth of the abrasion did not increase as much as those for untreated materials. When loads of 5 $\mathrm{N}, 7.5 \mathrm{~N}$, and $10 \mathrm{~N}$ were applied to the untreated material of SM45C, the coefficient of friction was approximately $0.76-0.78$. With the large specimen, a value of 0.72-0.78 was maintained at a load of $50 \mathrm{~N}$ despite the differences in the size of the wear specimen and working load. Tribological tests of large specimens of SM45C treated with UNSM under tribological conditions of $100 \mathrm{~N}$ and $50 \mathrm{~N}$ showed that the frictional coefficient and time constant stably converged between 0.7 and 0.8 . The friction coefficients of the small specimens treated with UNSM showed values between 0.78 and 0.75 under $5 \mathrm{~N}, 7.5 \mathrm{~N}$, and $10 \mathrm{~N}$. The friction coefficients of the SM45C treated with UNSM were comparable to each other.
\end{abstract}

\section{1. 서 론}

액화 천연가스(Liquefied natural gas, $\mathrm{LNG})$ 의 화물창은 $\mathrm{LNG}$ 의 운송을 위한 Loading과 Unloading의 반복으로 $111 \mathrm{~K}\left(-162^{\circ} \mathrm{C}\right)$ 에서 반복하중을 받게 된다. 또한, $\mathrm{LNG}$ 의 액압과 파도에 따른 움직 임으로 Sloshing(요동)이라는 유체유동의 효과에 의한 동적압력 하중 하에서 운전된다. 요동현상과 고압의 복합작용에 의해 멤 브레인(Membrane)의 파손을 방지하기 위해 멤브레인에 주름을 설치하는데 이 주름은 평판소재에 소성가공으로 성형된다(Chun et al., 2009; Kim et al., 2010; Kim et al., 2011).
LNG 선박용 내조 시스템에 사용되고 있는 멤브레인 재료는 성형성이 뛰어날 뿐 만 아니라 용접성, 내식성, 인장강도 및 피 로강도, 그리고 극저온에서 인성이 좋아야 한다. 이의 대표적인 재료는 $9 \% \mathrm{Ni}$ 강과 오스테나이트계 스테인레스강(STS 304L급) 등이 알려져 있다(Kim et al., 2011; Kim et al., 2013; Yu et al., 2013; Suh et al., 2016).

주로 금속판을 반복적으로 소성변형시켜 제품을 만드는 프레 스금형은 제품 정밀도를 유지하기 위해 부품의 내구성이 중요 하며, 이와 관련하여 내마모성과 마찰계수의 감소에 의한 소성 변형의 균일화가 확보되어야 한다(Amanov et al., 2012; Amanov

Received 7 August 2018, revised 28 October 2018, accepted 13 December 2018

Corresponding author Chang-Min Suh: cmsuh@knu.ac.kr ORCID: http://orcid.org/0000-0001-7034-8764

(c) 2018, The Korean Society of Ocean Engineers

This is an open access article distributed under the terms of the creative commons attribution non-commercial license (http://creativecommons.org/licenses/by-nc/3.0) which permits unrestricted non-commercial use, distribution, and reproduction in any medium, provided the original work is properly cited. 
et al., 2014; Gim and Jeong, 2007; Jeon et al., 2014; Lee et al., 2015; Pyun et al., 2012; Suh et al., 2016).

따라서 본 연구에서는 $\mathrm{LNG}$ 선박의 경량화와 안전성 확보를 위해서 이의 핵심요소인 멤브레인 소재인 STS 304L에 대한 주 름성형에 의해 발생된 소성변형의 영향을 트라이볼러지 (Tribology)적인 관점에서 평가하도록 한다. 즉 주름성형동안 발 생되는 소성변형률과 두께감소의 정도는 공정조건, 즉 금형설 계, 드로비드, 금형과 소재사이의 윤활, 금형의 표면처리 등에 크게 영향을 받게 된다.

본 연구에서는 주름성형용 금형의 표면처리와 윤활방법이 마 찰력에 어떤 영향을 미치는지 조사하기 위해 트라이볼러지 시 험을 실시하여 최적의 표면처리방법을 도출하기 위해 연구를 수행하였다. 즉 멤브레인 성형의 금형재질인 $\mathrm{SM} 45 \mathrm{C}$ 를 사용하 여 트라이볼러지 인자의 변화를 고려하면서 초음파나노표면개 질(UNSM, Ultrasonic nanocrystal surface modification) 표면처리 조건과 트라이볼러지 시험기의 하중조건에 따른 마찰계수의 특 성변화를 시험평가 함으로써 멤브레인 두께감소와 면굴곡을 최 소화할 수 있는 윤활방법과 표면처리방법을 선택할 수 있도록 자료를 축적하고자 한다(Amanov et al., 2012; Amanov et al., 2014; Gim and Jeong, 2007; Jeon et al., 2014; Lee et al., 2015; Pyun et al., 2012; Suh et al., 2016).

\section{2. 시험방법과 실험장비}

\subsection{UNSM처리기술과 장비}

Fig. 1(a)는 본 연구에 사용된 UNSM 기술용 장비의 구성요소 를 나타내었다. 즉 Fig. 1(a)와 같이 진동자(Tranducer, 20kHz), 부 스터(Booster), 혼(Horn)으로 되어있고, 혼의 선단에는 볼(Ball)과 볼을 고정시켜 주는 볼팁(Tip)이 있다. 연마한 금속에 UNSM 처 리를 하면 Fig. 2(a)와 같이 외관상 구분이 되며, 마이크로 딤플 (Dimple)(Fig. 1(b), Fig. 1(c))이 생성되면서 딤플 패턴을 형성하므 로 프리즘의 색상이 나타나게 되고, 이 표면은 연마한 표면보다 거칠기(Surface roughness)가 개선된다. 또한 금속표면에 1초당 20,000 번 이상의 타격을 통해 금속조직이 나노 구조화(Nano structure)로 되고, 표면경도가 향상되며, 크고 깊은 압축잔류응력 (Compressive residual stress)이 표면에 형성된다(Amanov et al., 2012; Amanov et al., 2014; Lee et al., 2015; Suh et al., 2007).

Table 1은 본 연구에 사용된 UNSM처리조건으로 기초자료에 의하여 $\mathrm{SM} 45 \mathrm{C}$ 에 가장 적합한 조건을 선택하였다. Fig. 1(b)는 $\mathrm{UNSM}$ 처리 후의 SM45C의 표면상태의 SEM(Scanning electron microscope)사진으로 규칙적인 가공 흔적을 확대사진에서 관찰 할 수 있다. 가공간격은 약 $2.6 \mu \mathrm{m}$ (2개의 화살표의 간격이 10.41 $\mu \mathrm{m}$ 이므로 4 개로 나눈 값)이다. Fig. 1 (c)는 $3 \mathrm{D}$ 로 관찰한 $\mathrm{AFM}$ (Atomic force microscope, SPA400, Japan) 사진으로 수평의 2축 은 $\mu \mathrm{m}$ 단위이고, 높이 축은 $\mathrm{nm}$ 로 관측된 사진이다. 여기서 규 칙적인 UNSM의 가공흔적 및 Micro dimple의 특성을 높이 축에 서 알 수 있다.

UNSM 처리조건은 Table 1 과 같지만 작용하중을 $30 \mathrm{~N}, 40 \mathrm{~N}$, $50 \mathrm{~N}$ 으로 달리하면서 3 가지 조건으로 UNSM처리하여 UNSM$30 \mathrm{~N}, \mathrm{UNSM}-40 \mathrm{~N}, \mathrm{UNSM}-50 \mathrm{~N}$ 으로 칭하였다.

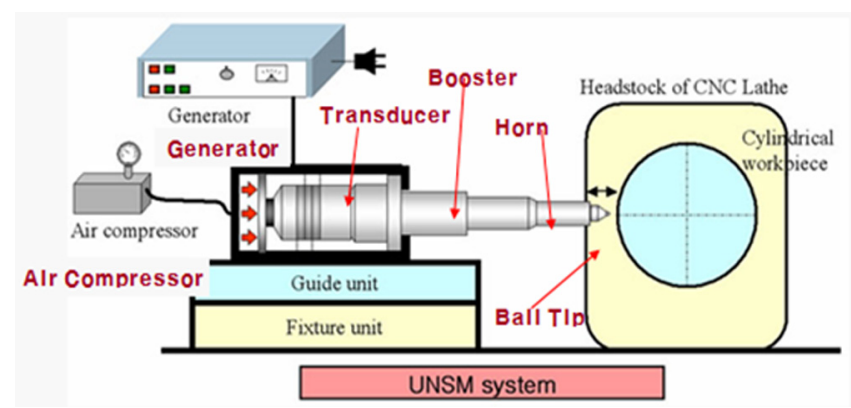

(a) UNSM equipment

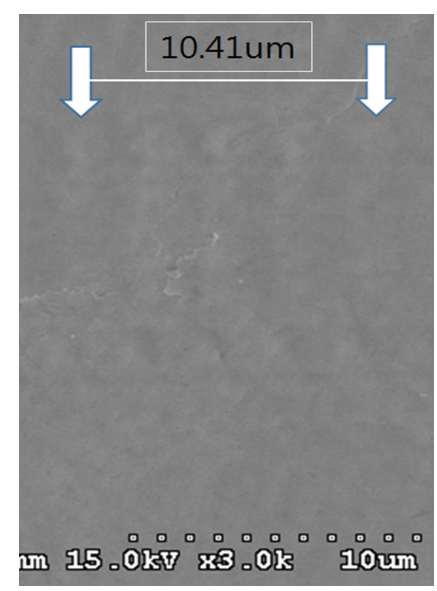

(b) SEM image $(3000 \times)$

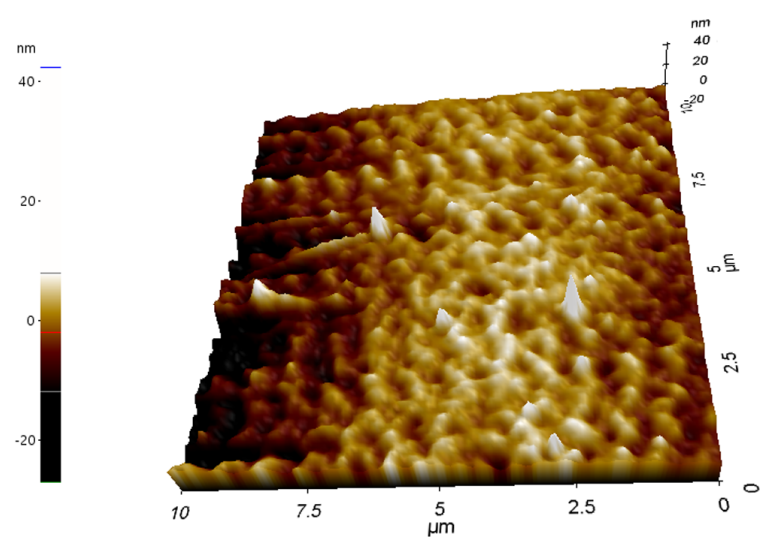

(c) 3D of Atomic Force Microscope (AFM) after UNSM treatment

Fig. 1 UNSM equipment and micro forging traces

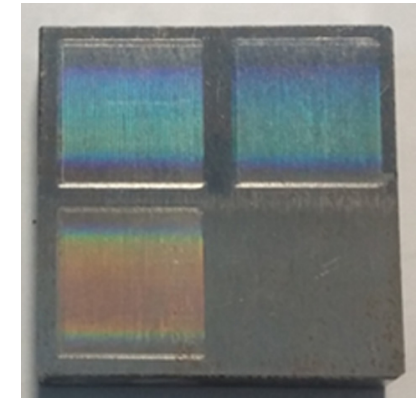

(a) For CSM tester

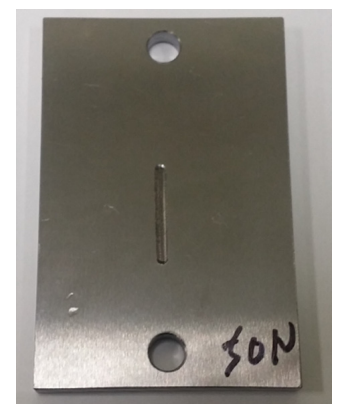

(b) For TE77 AUTO tester
Fig. 2 Configuration of the test specimens 
Table 1 UNSM conditions of SM45C

\begin{tabular}{ccccccc}
\hline \hline $\begin{array}{c}\text { Fre- } \\
\text { quency }\end{array}$ & $\begin{array}{c}\text { Ampli- } \\
\text { tude } \\
{[\mathrm{kHz}]}\end{array}$ & $\begin{array}{c}\text { Horn } \\
\text { speed }\end{array}$ & $\begin{array}{c}\text { Feed } \\
\text { rate }\end{array}$ & $\begin{array}{c}\text { Speed } \\
{[\mathrm{mm} / \mathrm{min}]}\end{array}\left[\begin{array}{c}\text { Load } \\
{[\mathrm{mm} / \mathrm{mev}]}\end{array}\right.$ & $\begin{array}{c}\text { Ball } \\
{[\mathrm{m}]}\end{array}$ & $\begin{array}{c}\text { Diameter } \\
{[\mathrm{mm}]}\end{array}$ \\
\hline 20 & 30 & 3,000 & 0.07 & 2,000 & $30,40,50$ & 2.38 \\
\hline
\end{tabular}

\section{$2.2 \mathrm{SM} 45 \mathrm{C}$ 의 시험편과 트라이볼러지 시험방법}

본 시험에서 사용한 마모시험편은 Fig. 2(a)와 같이 20×20× $5 \mathrm{~mm}$ 크기의 정사각형(Fig. 3(a)의 시험기용을 작은 시험편이라 칭한다.)와 Fig. 2 (b)와 같이 $38 \times 58 \times 4 \mathrm{~mm}$ 크기의 직사각형(Fig. 3 (b)용)인 SM45C재 시험편을 큰 시험편이라 칭하였고, 시험편 의 화학성분과 물성치는 Table 2 와 같다.

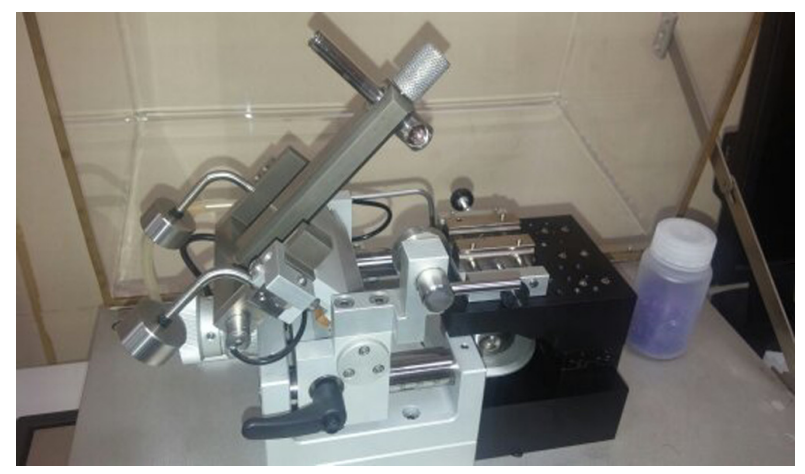

(a) CSM Instruments, Micro-tribo tester.

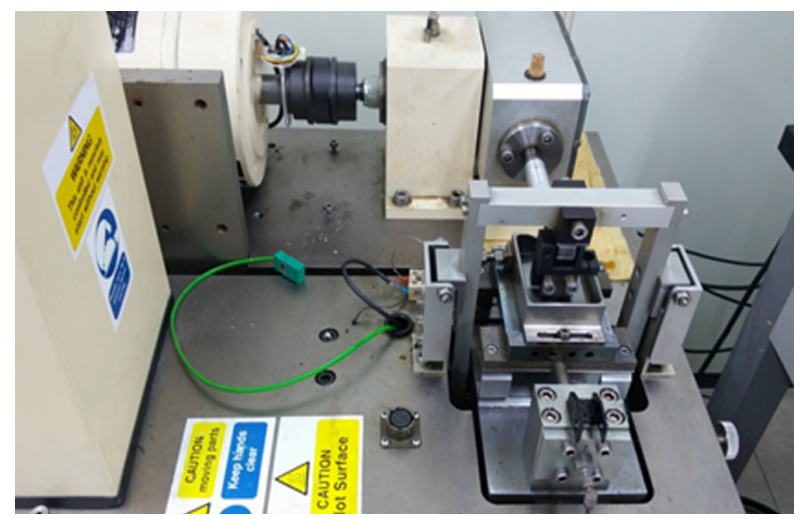

(b) TE77 AUTO, Plint \& partners,

Fig. 3 Tribology experimental apparatus

Table 2 Mechanical properties and chemical composition of SM45C [wt \%] $(U T=625 \mathrm{MPa}, Y P=530 \mathrm{MPa}$, Vickers $H v=210)$

\begin{tabular}{ccccc}
\hline \hline $\mathrm{C}$ & $\mathrm{Mn}$ & $\mathrm{P}$ & $\mathrm{S}$ & $\mathrm{Fe}$ \\
\hline $0.42 \sim 0.5$ & $0.6 \sim 0.9$ & $<0.04$ & $<0.04$ & $98.51 \sim 98.98$ \\
\hline
\end{tabular}

마찰 - 마모 시험의 조건은 Table 3과 같고, Fig. 3의 왕복식 트 라이볼러지 시험기를 사용하였다. 시험편의 표면조도는 SM45C 기계가공 후 연마하여 사용하였다.

이와 같이 작은 시험편은 Fig. 2(a)와 같이 3 가지 종류의
Table 3 Tribology test conditions of SM45C

\begin{tabular}{ccccccc}
\hline \hline $\begin{array}{c}\text { Specimen } \\
\text { type }\end{array}$ & $\begin{array}{c}\text { Load } \\
{[\mathrm{N}]}\end{array}$ & $\begin{array}{c}\text { Speed } \\
{[\mathrm{Hz}]}\end{array}$ & $\begin{array}{c}\text { Stroke } \\
{[\mathrm{mm}]}\end{array}$ & $\begin{array}{c}\text { Time } \\
{[\mathrm{min}]}\end{array}$ & $\begin{array}{c}\text { Counter part } \\
(\mathrm{SAE} 2100)\end{array}$ & Condition \\
\hline Small & $10,7.5,5$ & 2.5 & 15 & 25 & $d=5 \mathrm{~mm}$ & Dry \\
Large & 50,100 & 2 & 15 & 30,60 & $d=10 \mathrm{~mm}$ & Dry \\
\hline
\end{tabular}

$\mathrm{UNSM}$ 처리를 한 경우이며, 시험편 1개에 여러 조건의 시험을 시 행할 수 있고, 하중은 $5 \mathrm{~N}, 7.5 \mathrm{~N}, 10 \mathrm{~N}$ 에서 실시하였다. Fig. 2(b)의 큰 시험편은 1 조건 만의 실험이 가능하며, 목적에 따라 $50 \mathrm{~N}$ 과 $100 \mathrm{~N}$ 에서 1,800 초( $0.5 \mathrm{~h})$ 과 1,200 초( $0.3 \mathrm{~h})$ 에서 트라이볼러지 시험 을 실시하였다.

\section{3 시험장비}

본 연구에 사용된 트라이볼러지 시험장비는 Fig. 3(a)과 같이 작은 시험편용(CSM Instruments, Micro-tribo tester, Swiss)과 Fig. 3(b)와 같이 큰 시험편용(TE77 AUTO, Plint \& partners, England) 을 사용하였다.

표면 거칠기를 측정하기 위해 거칠기 측정 장비(Mitutoyo SJ-210, Japan)을 사용하였으며, 경도를 측정하기 위한 비커스경 도기(Mitutoyo MVK-E3, Japan)와 로크웰경도 측정 장비(Wolpert Testor 2000, Instron Corp. USA)를 사용하였다. Micro dimples를 확인하기 위해 $\mathrm{AFM}$ 을 사용하였다. 그리고 SEM사진은 FE-SEM (S-4300, Hitachi, Japan)장비를 사용했으며, 마모면의 형상은 표 면스크래치와 형상 측정 장비(Surfcom $1500 \mathrm{sd} 3$, Japan와 Form Talysurf PGI, Taylor Hobson, England)를 각각 사용하였다.

\section{3. 시험 결과 및 고찰}

\subsection{SM45C재의 미처리재와 UNSM처리재의 트라이볼러지 특성}

\subsection{1 표면 거칠기 변화}

Fig. 4는 작은 시험편으로 기계 가공한 상태인 미처리재와 $\mathrm{UNSM}$ 처리재 3 가지의 표면 거칠기를 비교하여 나타내었다. Fig. 4(a)는 평균 거칠기 $R a$ 이고, Fig. 4(b)는 거칠기 높이 $R z$, Fig. 4(c) 는 전체 Data를 모두 비교한 것으로 조도 $R z$ 의 값이 가장 큼은 마이크로 냉간단조 형식인 UNSM처리에 의하여 생긴 현상이다. 이때, 미처리재의 조도가 가장 크며, UNSM 처리재 중에는 정하 중을 크게 한 UNSM-50N의 조도가 UNSM-30N과 UNSM-40N에 비하여 크며, 정하중에 따라 $R a$ 가 거의 선형적으로 증가하는 경 향은 나타내었다. 이 자료중에 $R z$ 의 거칠기 값이 최대값을 나타 내므로, 최근 $R a$ 보다 신뢰성이 크다고 평가하는 경향이다.

\section{1 .2 경도치의 변화}

표면 경도는 Fig. 5와 같이 UNSM 처리전 $(H v, 210)$ 보다 UNSM$30 \mathrm{~N}$ 인 경우 225 로 $7.1 \%$ 상승하였고, UNSM-40N은 228 로 $8.6 \%$, UNSM-50N은 224로 $6.7 \%$ 상승되었다. 따라서 3가지를 평균하면 $7.5 \%$ 의 상승효과를 얻을 수 있었다.

이러한 Fig. 5의 경도치의 변화곡선에서 UNSM처리하면 모두 표면경도가 증가하고 선형으로 증가되는 경우가 일반적이지만 경우에 따라 국부적으로 경화가 아니고, 연화현상이 생겨 표면 


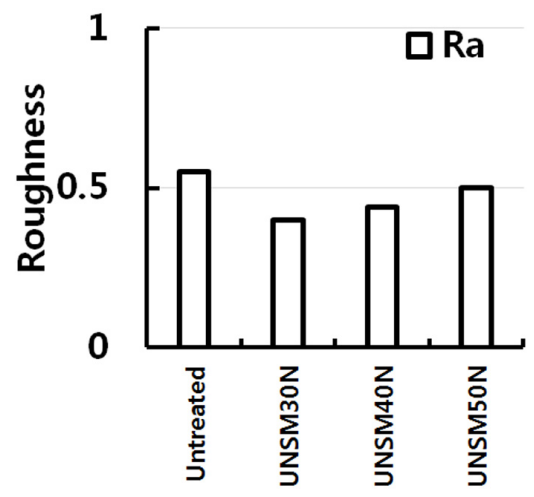

(a) Comparison of average surface roughness $R a$ before and after UNSM treatment [unit: $\mu \mathrm{m}$ ]

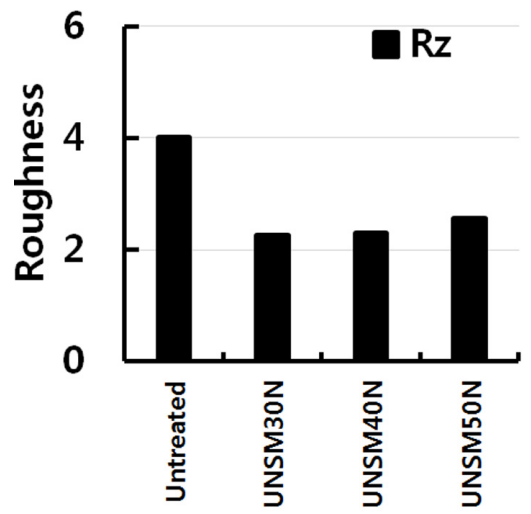

(b) Comparison of average surface roughness $\mathrm{Rz}$ before and after UNSM treatment [unit: $\mu \mathrm{m}$ ]

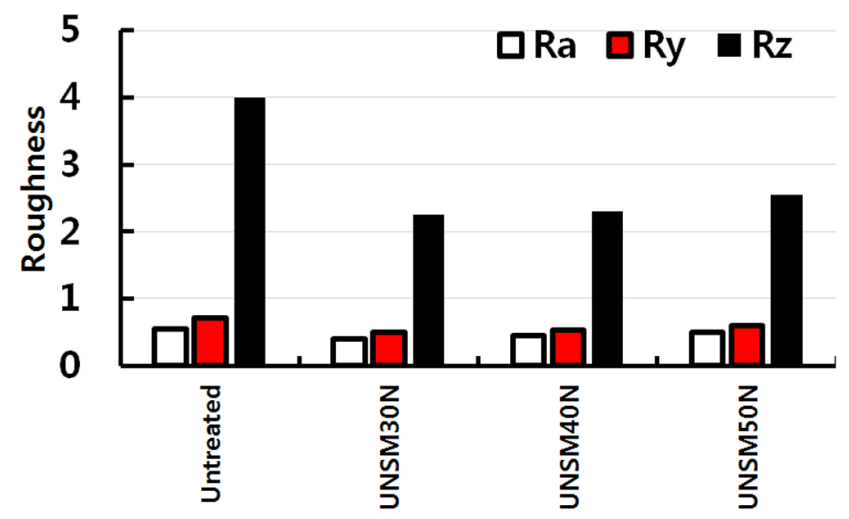

(c) Comparison of Ra, Ry, and Rz

Fig. 4 Comparison of average surface roughness $R a, R y$, and $R z$ before and after UNSM treatment [unit: $\mu \mathrm{m}$ ]

경도치가 떨어지는 경우가 생겼다. 이 결과를 재확인하기 위하 여 2 3차 $H v$ 경도시험을 실시했지만 Fig. 5와 같은 경향을 얻었 다. $H v$ 의 미소한 경도치의 변화는 측정위치에 따라 높게, 또는 낮게되는 현상이 생기거나, 일어나는 현상으로 $\mathrm{HRB}(B r i n e l l$ hardness)시험에서는 이런 현상은 없었다.

Fig. 5(b)는 큰 시험편으로 가공한 $\mathrm{SM} 45 \mathrm{C}$ 모재와 이 모재에 UNSM-30N, UNSM-40N, UNSM-50N의 3가지 조건으로 표면 처 리된 마모시험편의 표면 경도 $H R_{B}$ 를 측정하여 비교한 자료이 다. 이 그림에서 모재보다 UNSM 처리 재는 약 $2.4 \%$ 증가하는

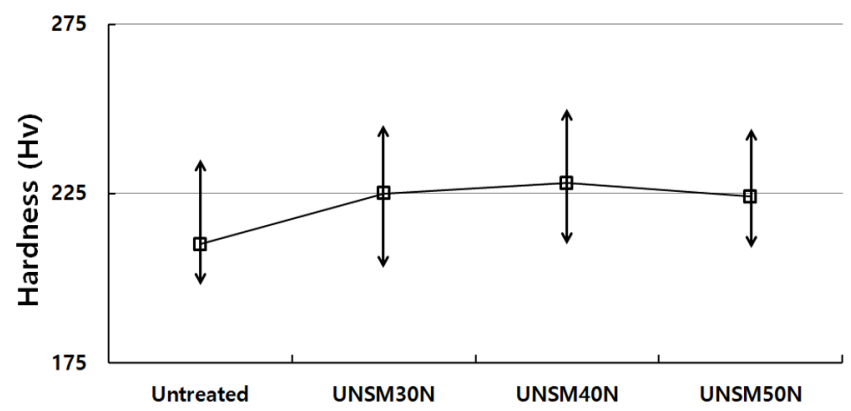

(a) Variation of Hv hardness depend on UNSM load

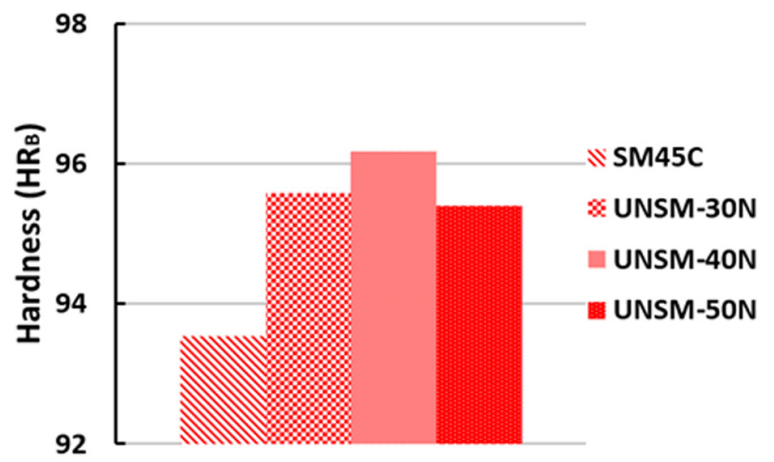

(b) Comparison of $\mathrm{HRb}$ hardness for untreated and UNSM-treated specimens

Fig. 5 Variation of hardness depend on UNSM load

경향을 나타내었다. 또한 3 가지 UNSM재의 정하중에 의한 차는 크지 않았다. 이러한 경도상승 현상은 조직의 나노화, 압축잔류 응력의 형성 등과 연관성이 크다고 보고되고 있다.

\subsection{3 미처리재의 하중에 따른 마찰계수 변화}

Fig. 6(a)는 Fig. 3(b)의 장비를 사용하여 SM45C 미처리재의 큰 시험편으로 트라이볼러지 시험한 결과를 시간에 따라 마찰 계수가 변화하는 상태를 나타내었다. Dry 조건으로 1,800 초까지 하중 $50 \mathrm{~N}$ 로 실시했을 때 마찰계수의 변화폭이 생겼지만 0.783 을 유지하였고, $100 \mathrm{~N}$ 에서는 $0.72( \pm 0.04)$ 값을 유지하였다. Fig. 6(a)의 자료는 하중 $100 \mathrm{~N}, 50 \mathrm{~N}$ 에 대한 마찰계수인데, UNSM처 리된 플레이트에 대한 볼 타입 상대재의 왕복운동의 특성으로 판단된다(Amanov et al., 2012).

Fig. 6(b)는 Fig. 6(a)의 시험한 시편을 천평으로 측정하여 무 게 감소량을 하중별로 비교하면 하중 $50 \mathrm{~N}$ 에 비하여 $100 \mathrm{~N}$ 의 하 중이 작용할 때의 무게 감소량이 약 $17 \%$ 감소하였다. 이것은 $\mathrm{SM} 45 \mathrm{C}$ 재와 같은 연성이 있은 재질에서 하중 $50 \mathrm{~N}$ 에 비하여 $100 \mathrm{~N}$ 의 하중에 의하여 마모 시에 나타나는 부분적인 가공경화 현상으로 판단된다.

Fig. 7은 SM45C재의 미처리재의 작은 시험편과 큰 시험편의 마 찰계수와 하중조건과의 관계를 막대그래프로 비교한 것이다. 즉 작은 시편의 미처리재의 마찰계수는 하중이 $5 \mathrm{~N}, 7.5 \mathrm{~N}, 10 \mathrm{~N}$ 의 결과 에서는 약 0.76 0.78 정도로 거의 비슷하게 나타났고, 큰 시편에서 는 Fig. $6(\mathrm{a})$ 와 같이 하중 $50 \mathrm{~N}$ 에서는 0.783 을 유지하였고, $100 \mathrm{~N}$ 에서 는 $0.72( \pm 0.04)$ 값을 유지하여, 마모시편과 작용하중의 크기의 차이 에도 불구하고 $0.72 \sim 0.78$ 의 비슷한 마찰계수를 나타내었다. 


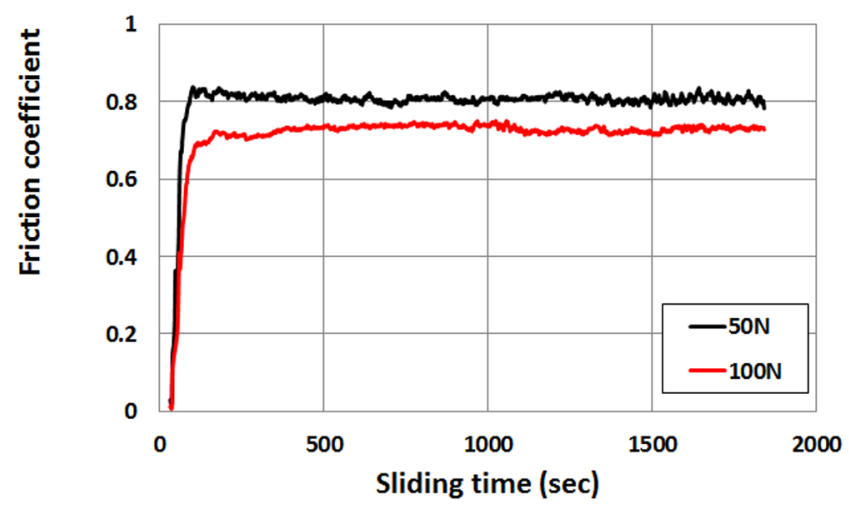

(a) Variation in friction coefficient of the untreated specimen as a function of reciprocating sliding time at a normal load of $50 \mathrm{~N}$ and $100 \mathrm{~N}$ under reciprocating dry sliding conditions

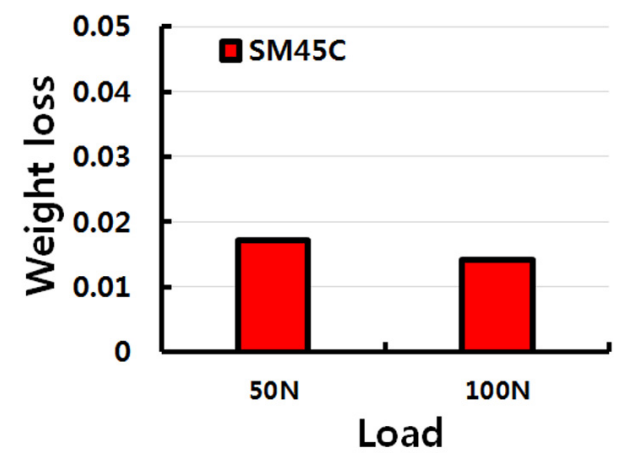

(b) Variation in weight loss of untreated specimen

Fig. 6 Variation in friction coefficient and weight loss

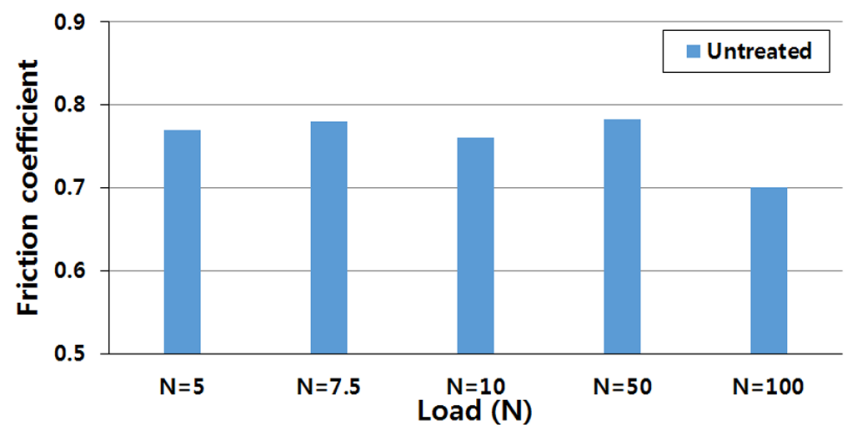

Fig. 7 Relationship between friction coefficient and normal loads

3.1.4 UNSM 처리 조건과 하중에 따른 작은 시편의 마찰계수 의 특성 변화

Fig. 8(a)와 Fig. 8(b)는 작은 시편으로 트라이볼러지 시험한 시편의 결과를 마모된 거리로 마찰계수를 도시한 결과를 예시 한 것이다. 이 두 그림은 UNSM-50N과 UNSM- $40 \mathrm{~N}$ 처리재의 결 과로 하중에 따라 약간의 차이는 있어도 마찰계수는 0.75 0.8사 이에 변동하면서 서로 비슷한 특성을 나타내었다.

Fig. 8(c)는 Fig. 8(a)와 Fig. 8(b) 같은 자료를 사용하여 마찰계 수의 변화를 막대그래프로 비교한 것이다. 이때 마찰계수가 수 렴하면서 안정적인 값을 취할 때를 선택하였으며, 하중이 $7.5 \mathrm{~N}$ 과 $5 \mathrm{~N}$ 인 경우는 마찰계수가 $0.77 \sim 0.78$ 사이의 값을 보였다. 여 기서 미처리재에 비교하여 작은 마모시험편의 작용하중이 $5 \mathrm{~N}$,

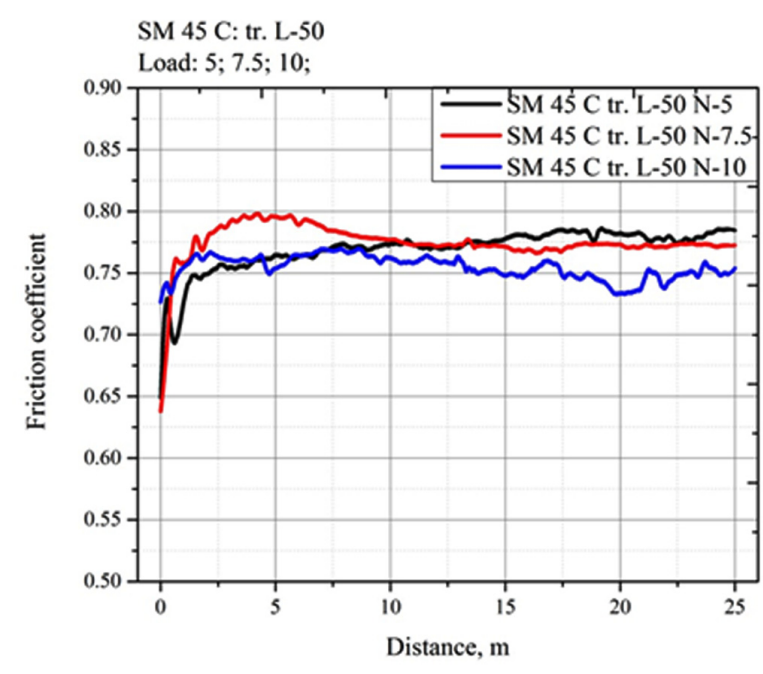

(a) UNSM treated specimen at $50 \mathrm{~N}$

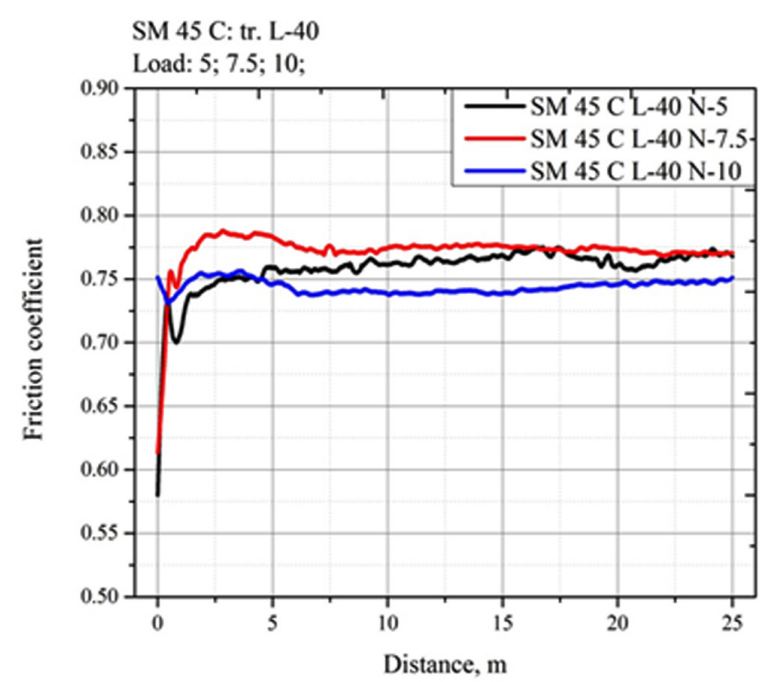

(b) UNSM treated specimen as $40 \mathrm{~N}$

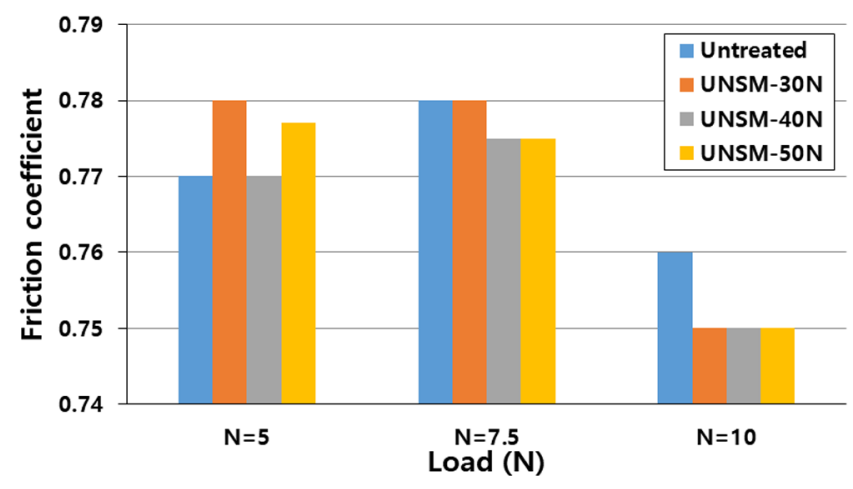

(c) At a normal load of $5 \mathrm{~N}, 7.5 \mathrm{~N}$, and $10 \mathrm{~N}$

Fig. 8 Variation in friction coefficient of UNSM treated specimen as a function of static loads $50 \mathrm{~N}$ (a) and $40 \mathrm{~N}$ (b) at a normal load of $5 \mathrm{~N}, 7.5 \mathrm{~N}$, and $10 \mathrm{~N}$

$7.5 \mathrm{~N}$ 인 경우는 $10 \mathrm{~N}$ 보다 마찰계수가 증가하는 경향을 나타내었 지만 $10 \mathrm{~N}$ 에서는 마찰계수가 감소하는 경향이 나타내었다. 특히 $10 \mathrm{~N}$ 의 경우는 $7.5 \mathrm{~N}$ 보다 $3.2 \%$ 감소하는 경향을 나타내었다. 
3.1.5 UNSM 처리 조건과 하중에 따른 큰 시편의 마찰계수의 특성 변화

Fig. 9(a)와 Fig. 9(b)는 정하중을 $30 \mathrm{~N}, 40 \mathrm{~N}, 50 \mathrm{~N}$ 의 3 가지 조건 으로 UNSM 처리된 UNSM-30N, UNSM-40N, UNSM-50N의 큰 시험편에 Fig. 3(b)의 시험 장치로 $100 \mathrm{~N}$ 과 $50 \mathrm{~N}$ 하에 트라이볼러 지 시험하여 마찰계수와 시간과의 관계를 각각 나타내었다. 이 트라이볼러지 시험결과에서 3 가지 UNSM 처리재는 하중이 큰 $100 \mathrm{~N}$ 의 경우가 마찰계수가 0.7 에 수렴하였고, $50 \mathrm{~N}$ 의 경우는 0.8 에 수렴 후 UNSM-30N재는 마찰계수가 약간 감소하면서 안정 된 경향을 나타내었다. 따라서 Fig. 8(c)의 작은 시험편의 마찰 계수의 특성과 비교하면 큰 시험편은 $0.7 \sim 0.8$ 로 비슷한 경향을 나타낸 것이다. 이러한 마찰계수의 특성은 UNSM 처리에 따른 효과에 의한 것으로 재료특성과 마멸 폭과 깊이에도 연관성이 있을 것으로 예상된다.

$\mathrm{SM} 45 \mathrm{C}$ 재의 미처리재보다 UNSM 처리재의 마찰계수가 감소하 는 경향이지만 Fig. 8(a)와 같이 마찰거리에 따라 그렇지 않는 경 우도 공존하였다. 이것은 $\mathrm{SM} 45 \mathrm{C}$ 재가 다른 연구자들의 금형재료 보다 연하고 변형이 잘 되는 재료의 특성에서 생기는 것으로 예 상된다(Amanov et al., 2012; Amanov et al., 2014; Lee et al., 2015). 초경과 같이 경한 프레스금형에서는 UNSM 처리하여 트라이볼 러지 시험하면 Fig. 10과 같이 마찰계수가 미처리재는 0.6 0.68, $\mathrm{UNSM}$ 처리재는 $0.5 \sim 0.55$ 로 되었다는 연구와 같이 경한 재료에 는 UNSM 처리의 효과가 커지만 본 연구에 사용된 연한 재료인 $\mathrm{SM} 45 \mathrm{C}$ 재에는 그 효과가 커지 않았다(Gim and Jeong, 2007).

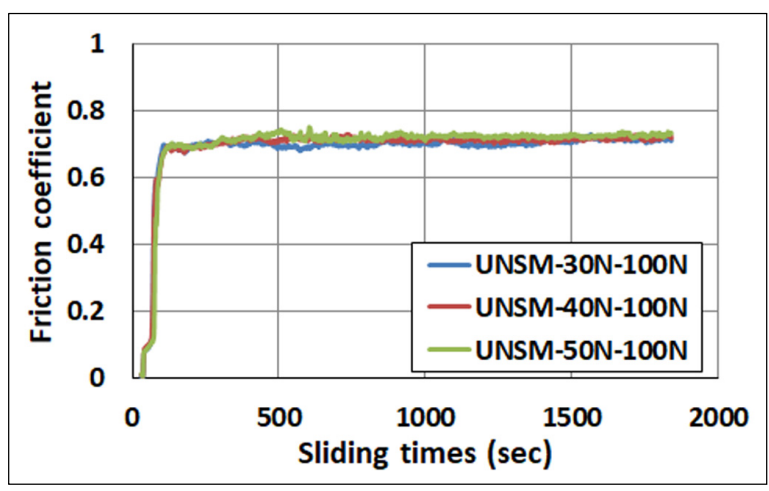

(a) At a normal load of $100 \mathrm{~N}$

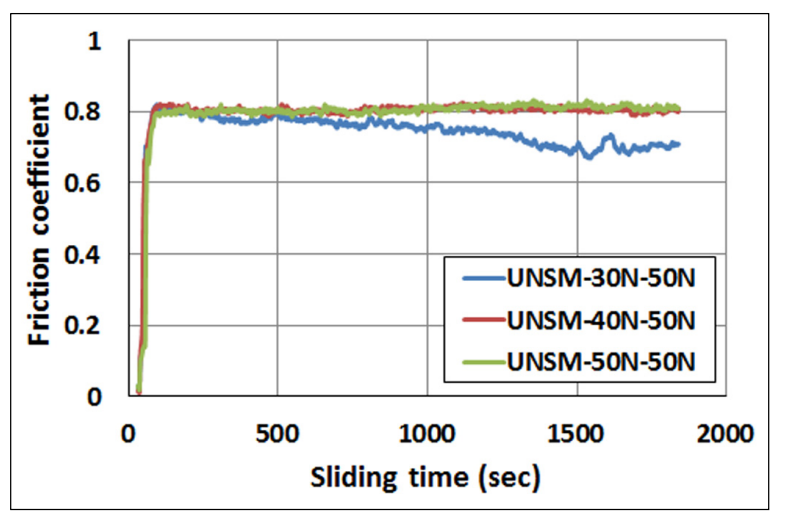

(b) At a normal load of $50 \mathrm{~N}$

Fig. 9 Variation in friction coefficient of UNSM treated specimen as a function of static loads $30 \mathrm{~N}, 40 \mathrm{~N}$ and $50 \mathrm{~N}$

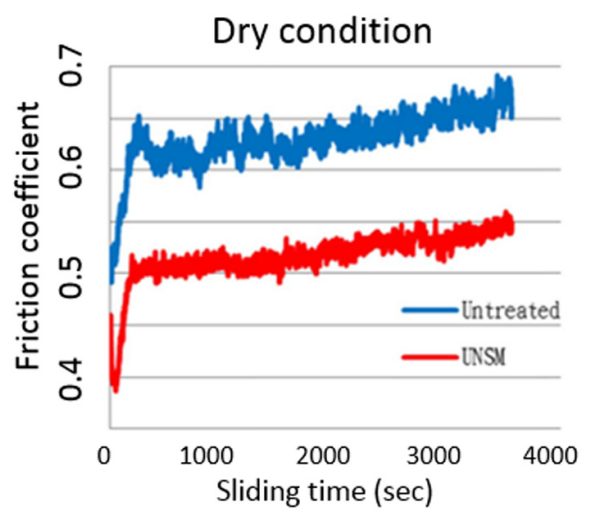

Fig. 10 Comparison of friction coefficient before and after UNSM treatment of carbide hardened materials

Fig. 11과 Table 4는 Fig. 9의 자료를 얻을 때, 즉 SM45C 모재 에 UNSM 처리된 3 가지 조건으로 처리된 큰 시험편의 트라이볼 러지 시험에서 1,800 초 후의 무게 감소량을 하중별로 정리한 자 료이다. 이 자료에서 수직하중 $50 \mathrm{~N}$ 의 조건보다 $100 \mathrm{~N}$ 의 조건에 서 마모량이 약간 감소하였으나, 마멸량의 차이는 적으며, Fig. 6(b)의 미처리재에서도 같은 현상이 생겼다. 이러한 중량 감소 현상에 따른 현상은 SM45C 모재의 특성과 마멸폭과 마멸깊이 변화와 연관성이 크므로 3.1.6에서 다시 검토한다.

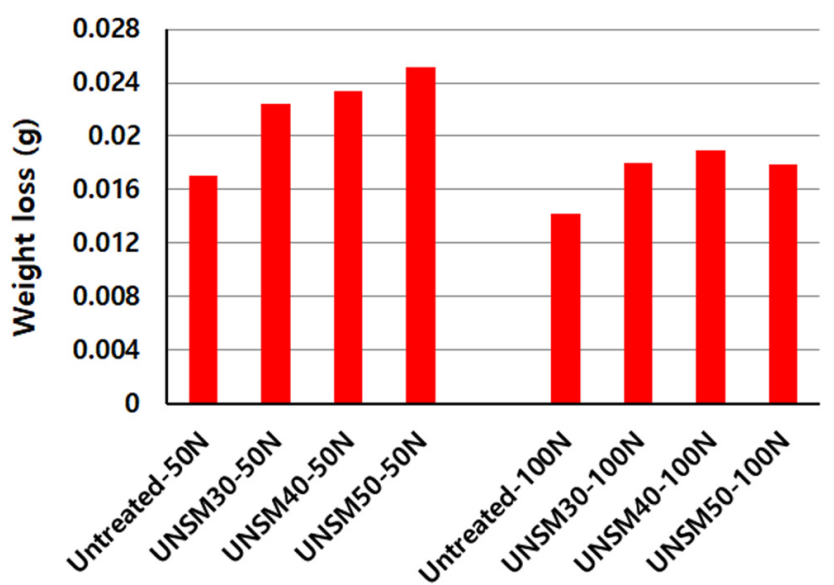

Fig. 11 Variation in weight loss of UNSM treated specimen

Table 4 Comparison of weight loss of the untreated specimen, and UNSM treated specimens

\begin{tabular}{ccc}
\hline \hline \multirow{2}{*}{ Specimen } & \multicolumn{2}{c}{ Weight loss $[\mathrm{g}]$} \\
\cline { 2 - 3 } & $50 \mathrm{~N}$ & $100 \mathrm{~N}$ \\
\hline Untreated & 0.0171 & 0.0142 \\
UNSM-30 & 0.0224 & 0.0180 \\
UNSM-40 & 0.0234 & 0.0189 \\
UNSM-50 & 0.0252 & 0.0179 \\
\hline
\end{tabular}

\subsection{6 마모 궤적과 마모 깊이의 변화}

Fig. 12는 작은 시험편으로 실시한 트라이볼러지시험의 결과 를 마모 궤적(Wear track profile)으로 정리한 것이다. 미처리재와 UNSM 처리재 3 가지를 동시에 나타내었고, 이 그림에서 마모궤 


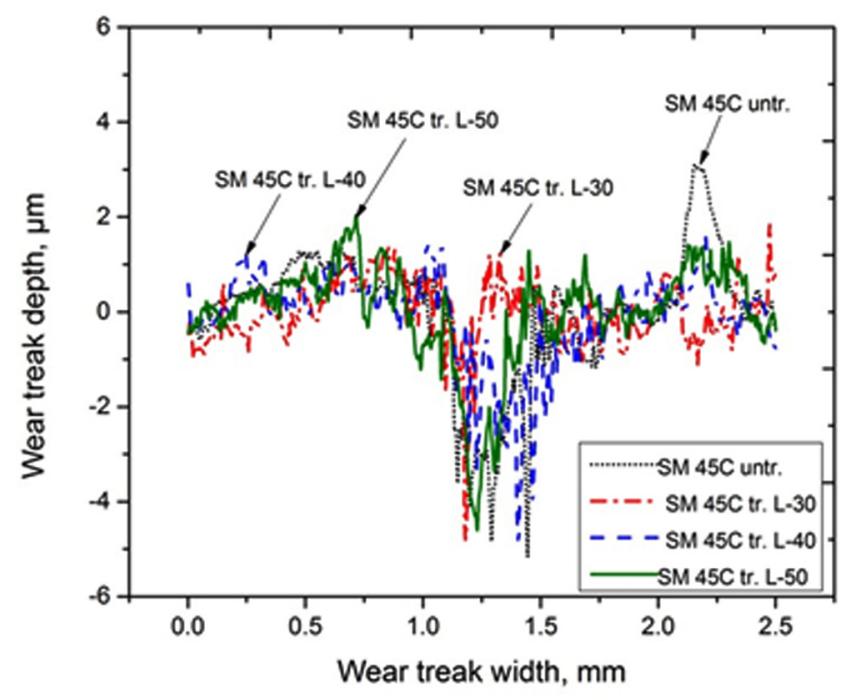

Fig. 12 Cross-sectional wear track profiles of the untreated and UNSM-treated specimens

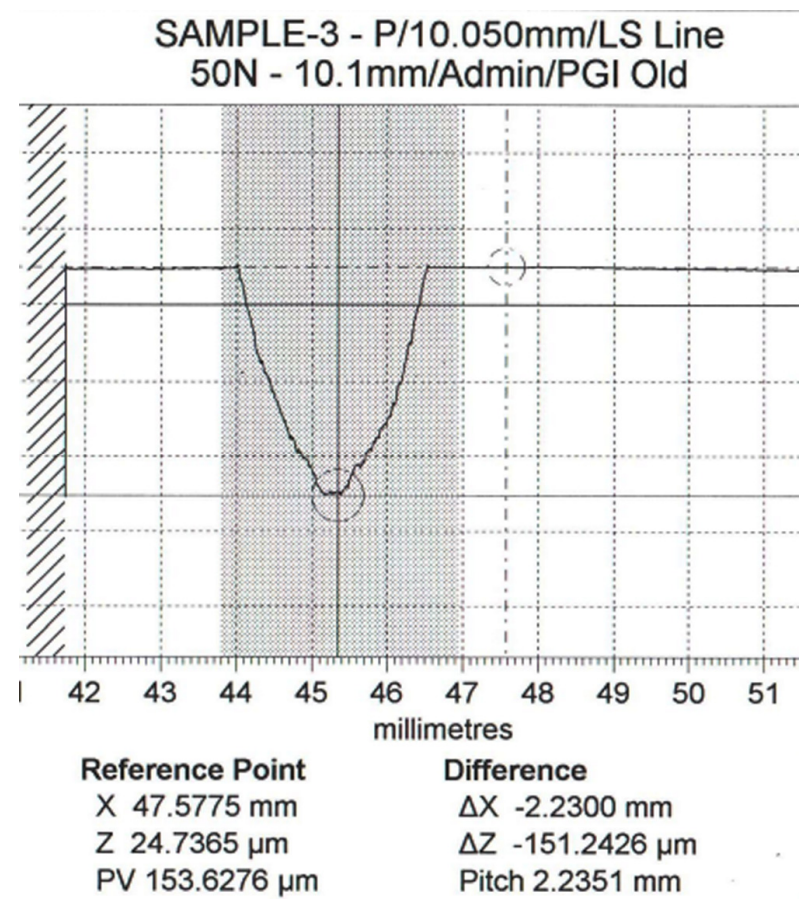

Fig. 13 Sample of wear depth by Taylor Hobson tester

적의 변화특성의 일관성을 나타내었다. $1.3 \mathrm{~mm}$ 에서 $1.5 \mathrm{~mm}$ 사이 에 마모궤적의 깊이의 값이 감소하는 의미는 1 차 마모궤적이므 로 생긴 현상이다. 추가로 마모궤적을 추가하면 그 폭이 넓어지 는 현상이 예상된다.

Fig. 13은 큰 트라이볼러지 시험편을 사용하여 Fig. 9와 Fig. 11 의 자료를 얻을 때, 즉 $50 \mathrm{~N}$ 과 $100 \mathrm{~N}$ 하에서 실시된 시험결과를 거칠기 측정 장치(Taylor Hobson tester)를 사용하여 마모폭과 마 모깊이를 측정한 예이다. 즉 Fig. 13과 같은 측정결과를 출력받 아, 그 자료를 각각 스캔하여 정리하면서 마모의 최대 폭은 Fig. 14(a)에, 마모의 최대 깊이는 Fig. 14(b)로 나타내었고, 그 특성을 Table 5와 같이 정리하였다.

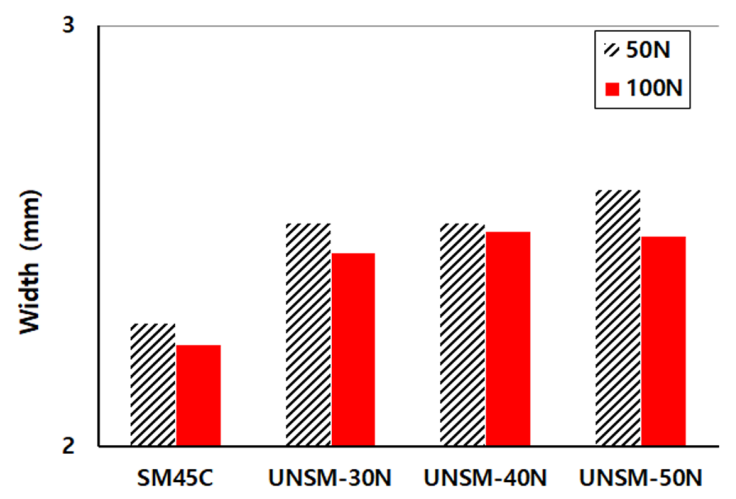

(a)

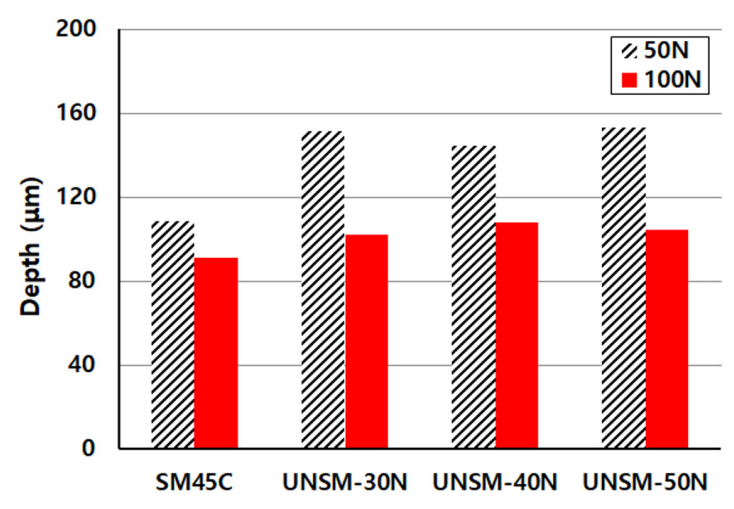

(b)

Fig. 14 Variation in wear width and depth to static load and specimen conditions at a normal load of $50 \mathrm{~N}$, and $100 \mathrm{~N}$

Table 5 Comparison of wear width and depth to static load and specimen conditions

\begin{tabular}{ccccc}
\hline \hline \multirow{2}{*}{ Specimen } & \multicolumn{2}{c}{$50 \mathrm{~N}$} & \multicolumn{2}{c}{$100 \mathrm{~N}$} \\
& $\begin{array}{c}\text { Width } \\
{[\mathrm{mm}]}\end{array}$ & $\begin{array}{c}\text { Depth } \\
{[\mathrm{mm}]}\end{array}$ & $\begin{array}{c}\text { Width } \\
{[\mathrm{mm}]}\end{array}$ & $\begin{array}{c}\text { Depth } \\
{[\mathrm{mm}]}\end{array}$ \\
\hline SM45C & 2.29 & 0.108 & 2.24 & 0.091 \\
UNSM-30 & 2.53 & 0.145 & 2.46 & 0.108 \\
UNSM-40 & 2.53 & 0.151 & 2.51 & 0.102 \\
UNSM-50 & 2.61 & 0.153 & 2.50 & 0.105 \\
\hline
\end{tabular}

Fig. 14와 Table 5의 자료에서 트라이볼러지 시험 후의 시험편 중앙부의 표면 거칠기의 최대폭과 최대 깊이는 미처리재인 $\mathrm{SM} 45 \mathrm{C}$ 와 같이 UNSM-30N, UNSM-40N, UNSM-50N으로 표면 처리된 3 가지 시험편에는 트라이볼러지 시험시의 하중이 2 배로 크지만 그 차이가 매우 적다. 특히 최대깊이에서는 하중이 $100 \mathrm{~N}$ 인 경우가 $50 \mathrm{~N}$ 보다 적어지는 경향은 연성재료의 마모에 의한 국부적인 가공경화현상으로 예상된다. 이 현상은 SEM관 찰에서 다시 분석하기로 한다.

또 UNSM 처리효과가 트라이볼러지 현상에 생기는 것은 Fig. 15 와 같이 다른 연구에서 얻은 자료이지만, UNSM 처리재는 표 면조직의 나노화가 약 $120 \mu \mathrm{m}$ 까지 형성되었고, 표면경도의 상 승과 깊고 큰 압축잔류응력의 형성에 원인이 있는 것 같다(Pyun et al., 2012; Suh et al., 2007). 

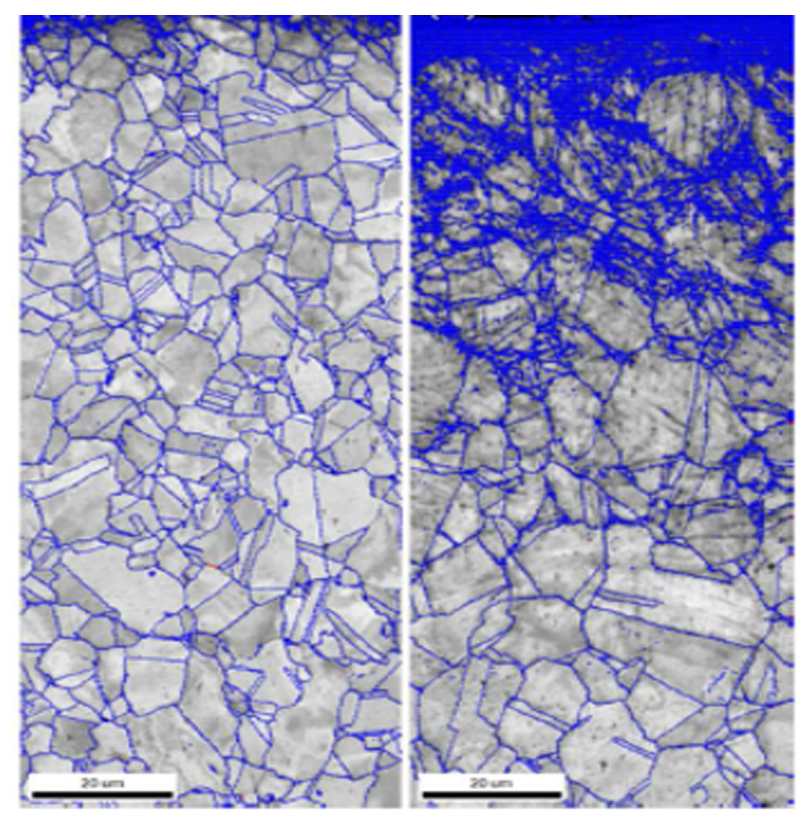

(a)

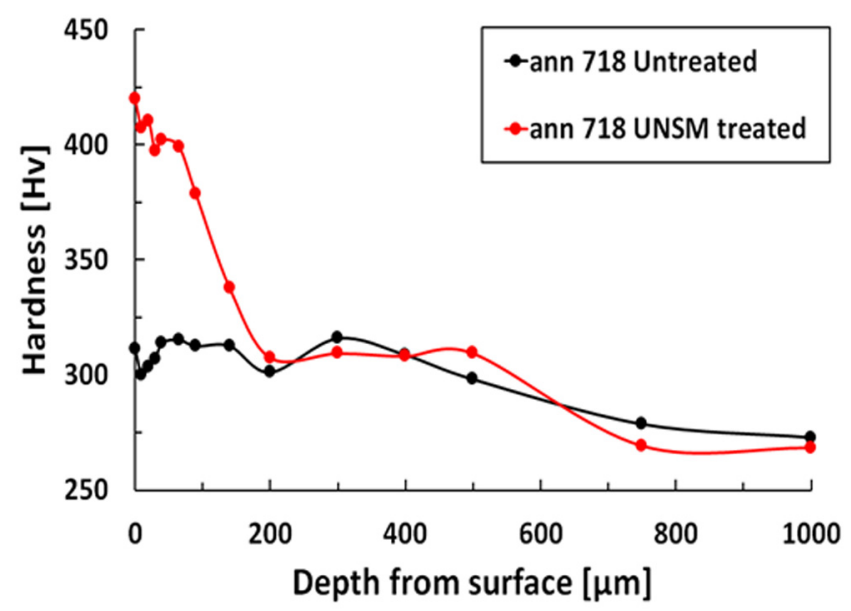

(b)

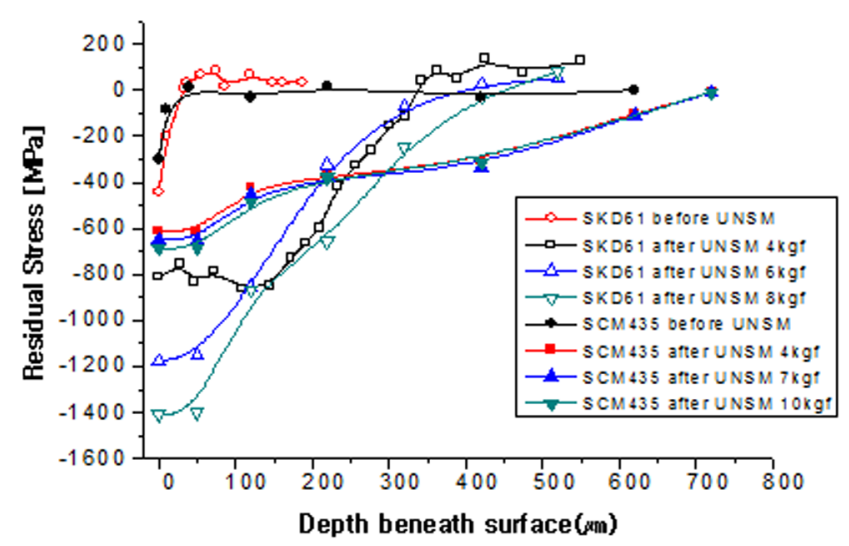

(c)

Fig. 15 The UNSM treated material seems to be caused by nanozation of surface texture (a), surface hardness increase (b) and formation of deep and large compressive residual stress (c) (Pyun et al., 2012; Suh et al., 2007)

\section{2 트라이볼러지 시험후의 SEM관찰 결과}

\subsubsection{SM45C재의 미처리재의 $\mathrm{SEM}$ 관찰 결과}

Fig. 16은 큰 시편의 중앙부를 SEM 관찰 한 것으로, 트라이볼 로지 시험 약 20 초 후의 미처리 소재의 표면을 예시한 것이다. Fig. 16(a)는 1000×, Fig. 16(b)는 3000×로 각각 확대한 것이지만, 특별한 마멸흔적(Wear trace)은 찾을 수가 없다. 마찰과 마모가 시작되는 초기조건으로 표면돌기(Asperity)들에 의한 마멸로 마 이크로 그루브가 형성되는 것을 볼 수 있다.

Fig. 17(a)는 미처리재에 작용하중 $50 \mathrm{~N}$ 에서 1,800 초(0.5 시간) 후의 마모상태이다. Fig. 17(b)는 Fig. 17(a)의 마모된 중앙부를 $30 \times$ 배율로 SEM관찰한 결과이고, Fig. 17(b)에는 마모흔적을 2 개의 화살표로 나타내었다. 이 폭은 SEM 관찰과 거칠기 시험기 에서는 $1.89 \mathrm{~mm}$ 로 측정되었고, 마멸트랙의 좌우는 기계가공으로 인한 방향성이 보인다.

Fig. 17(b)에는 융착 미끄럼(Adhesive sliding, Ad-S) 영역이 마 멸흔적 내에 진한 색으로 잘 나타내었다. 또 Fig. 17(b)의 사각 형으로 표시한 부분을 $100 \times$ 확대하면 융착 미끄럼이 관찰되었 고 융착마멸(Adhesive wear, Ad-W) 또한 관찰되었다. 융착 미끄 럼은 연성재료에서 주로 나타나며 볼-플레이트 미끄럼 접촉 시 에 플레이트를 볼이 누르며 지나가면서 발생하는 주요한 현상 으로 미끄럼과 열에 의한 소재의 소성변형에 기인한 것이다. 미 끄럼운동 시에는 특성이 방향성을 가지고 일관되게 나타나지만, 본 실험은 왕복운동이므로 상대적으로 확인되지 않았다.

Fig. 18은 Fig. 17(c)부분을 다시 확대한 SEM 사진으로 500배 와 1,000 배로 각각 확대하였고, Ball-on plate 왕복운동이라 방향

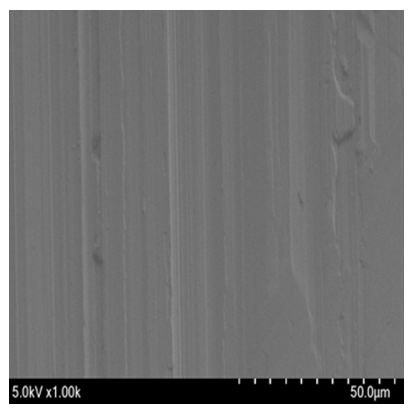

(a)

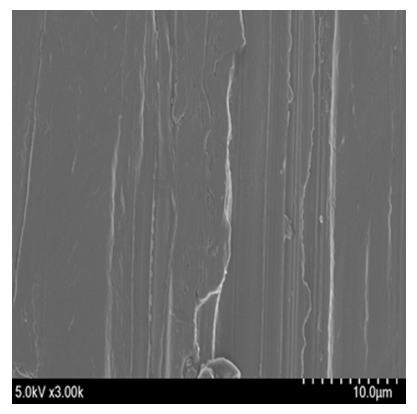

(b)
Fig. 16 SEM images of micro wear grooves for the untreated SM45C specimen after $20 \mathrm{sec}$. of the tribology test

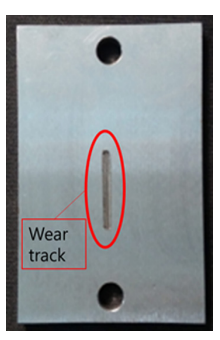

(a)

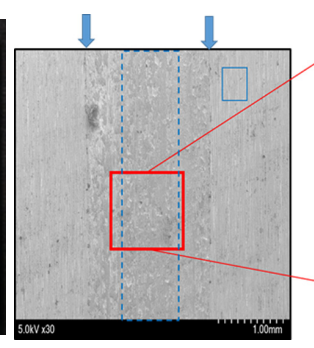

(b)

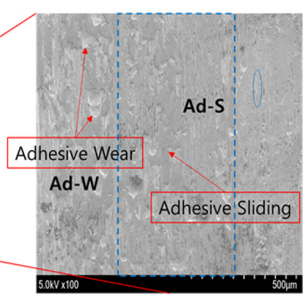

(c)
Fig. 17 Specimen and SEM images $(30 \times, 100 \times)$ at the center of wear track of untreated specimen. (a) specimen surface, (b) mag. of $30 \times$, and (c) mag. of $100 \times$ 


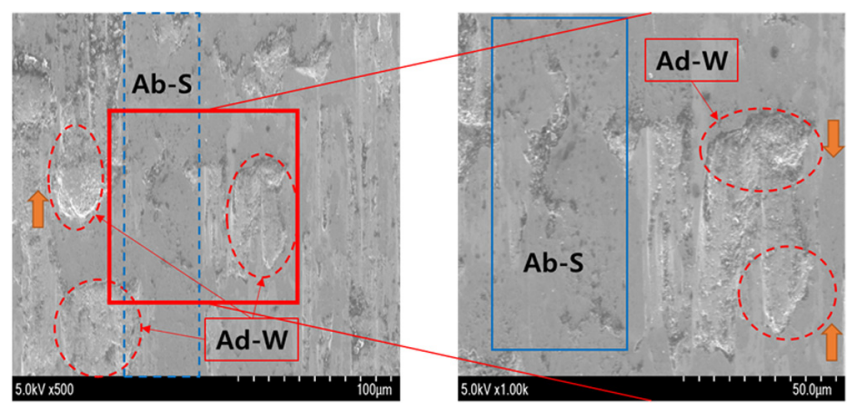

Fig. 18 SEM images $(500 \times, 1000 \times)$ at the center of wear track of untreated specimen.

성은 없지만, 융착 미끄럼 영역과 융착 마멸 부분이 눈에 띄게 관찰되며 입자들에 의한 연삭미끄럼(Abrasive sliding, $\mathrm{Ab}-\mathrm{S}$ ) 영 역은 상부 볼의 미끄럼접촉 운동에 의해 소재가 소성변형을 하 며 지나간 자국이다.

Fig. 18 에서는 $\mathrm{Ab}-\mathrm{W}$ 가 생성된 방향이 관찰되는 데 왕복운동 중에 생성된 $\mathrm{Ab}-\mathrm{S}$ 영역에서 소성변형아래 방향으로 내려오면서 또는 위 방향으로 이동하면서 발생된 $\mathrm{Ab}-\mathrm{W}$ 의 방향성을 화살표 로 각각 표기하였다. 소성변형이 된 영역이 떨어져 나가는 것이 트라이볼러지 거동의 순서가 되므로, 마멸 면은 언제 어느 방향 으로 마멸이 발생하였는지 예측할 수 있는 정보를 담고 있다.

일반적으로 소재의 마멸량은 소재의 경도, 적용하중과 미끄럼 거리에 의해서 결정되는데, 소재의 마멸량은 부품의 수명에서 시스템의 내구성까지 크고 작은 영향을 미친다. $\mathrm{Ab}-\mathrm{S}$ 와 같은 소 성변형이 발생될지, $\mathrm{Ab}-\mathrm{W}$ 와 같은 응착마멸이 발생되는지는 소 재의 경도, 접촉의 종류, 미끄럼 속도, 소재의 접착에 대한 표면 에너지(Surface energy of adhesion)와 마찰계수의 영향을 받는다 고 판단된다.

\subsubsection{UNSM재의 $\mathrm{SEM}$ 관찰 결과}

Fig. 19와 Fig. 20은 SM45C재에 UNSM-30N과 UNSM-50N로 표면처리 된 시험편의 트라이볼러지 파면 중앙부의 SEM사진을 예시한 것이다. 이 두 그림에서 Fig. 18과 같이 관찰된 Ball-On

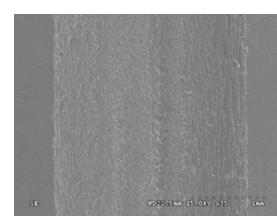

(a)

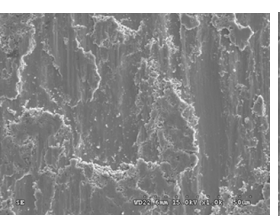

(b)

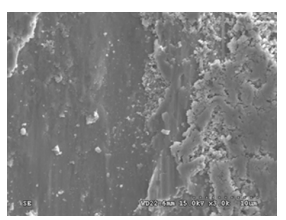

(c)
Fig. 19 SEM images $(30 \times(a), 1000 \times(b), 3000 \times(c))$ at the center of wear track of UNSM-30 N under the normal load $50 \mathrm{~N}$

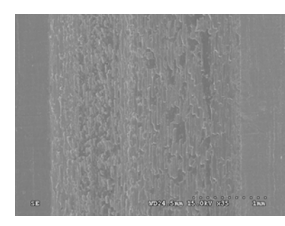

(a)

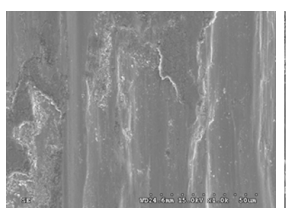

(b)

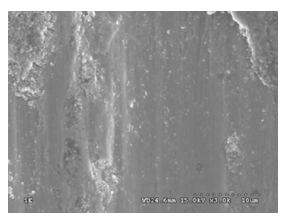

(c)
Fig. $20 \mathrm{SEM}$ images $(30 \times(a), 1000 \times(b), 3000 \times(c))$ at the center of wear track of UNSM-50 N, and load $50 \mathrm{~N}$
Plate 왕복운동이라 방향성은 없지만, 연삭마모로 떨어져나가는 부분과 융착마모와 연삭마모로 인한 변형이 관찰되며, $3000 \times$ 에 서는 그러한 Debris가 확대 관찰되었다.

\section{4. 결 론}

$\mathrm{SM} 45 \mathrm{C}$ 재의 미처리재와 UNSM 처리 전, 후에 트라이볼러지 시험을 실시하여 프레스 금형용 마찰계수를 낮추는 자료를 축 적하기 위한 일련의 연구에서 다음과 같은 결과를 얻었다.

$\mathrm{SM} 45 \mathrm{C}$ 재의 미처리재에 $5 \mathrm{~N}, 7.5 \mathrm{~N}, 10 \mathrm{~N}$ 의 하중이 작용할 때, 마찰계수가 약 0.76 0.78정도로 거의 비슷하게 나타났고, 큰 시 편에서는 하중 $50 \mathrm{~N}$ 에서는 0.783 을 유지하였고, $100 \mathrm{~N}$ 에서는 0.72 값을 유지하여, 마모시편과 작용하중의 크기의 차이에도 불구 하고 $0.72 \sim 0.78$ 의 비슷한 마찰계수를 나타내었다.

$\mathrm{UNSM}$ 처리된 $\mathrm{SM} 45 \mathrm{C}$ 재의 큰 시험편을 $100 \mathrm{~N}$ 과 $50 \mathrm{~N}$ 하에 트라 이볼러지 시험하여 마찰계수와 시간과의 관계를 나타낸 마찰계 수는 0.7 0.8 사이에 안정적으로 수렴하였다. UNSM처리된 작은 시험편의 마찰계수는 $5 \mathrm{~N}, 7.5 \mathrm{~N}$ 와 $10 \mathrm{~N}$ 하에서 $0.78 \sim 0.75$ 사이의 값을 나타내어 서로 비슷한 경향을 나타내었고, SM45C재의 $\mathrm{UNSM}$ 처리에 따른 마찰계수는 서로 비슷하였다.

$\mathrm{SM} 45 \mathrm{C}$ 재의 $\mathrm{UNSM}$ 처리재는 표면조직의 나노화, 높은 표면경 도와 깊은 큰 압축잔류응력 형성 등으로 작용하중이 2 배로 증 가해도 마모, 마멸에 의한 중량감소량, 마멸폭과 깊이가 미처리 재처럼 크게 증가하지 않은 경향을 나타내었다.

\section{후 기}

본 연구는 KEIT의 조선해양산업핵심기술개발사업(과제번호 : 10077592)과 산업통산자원부의 산업기술혁신개발사업(10067485) 의 지원으로 수행되었습니다.

\section{References}

Amanov, A., Cho, I.S., Pyoun, Y.S., Lee, C.S., Park, I.G., 2012. Micro-dimpled Surface by Ultrasonic Nanocrystal Surface Modification and its Tribological Effects. Wear, 286-287.

Amanov, A., Cho, I.S., Sasaki, S., 2014. The Influence of DLC Coating on the Mechanical and Frictional Properties of Unpeened and Peened Cu-based Bimetal under Dry Sliding Conditions. Materials Chemistry and Physics, 143, 814-824.

Chun, M.S., Kim, M.H., Kim, W.S., Kim, S.H., Lee, J.M., 2009. Experimental Investigation on the Impact Behavior of Membrane Type LNG Carrier Insulation System. Journal of Loss Prevention in the Process Industries, 22(6), 901-907.

Gim, J.S., Jeong, Y.T., 2007. Introduction to PVD/PACVD Coating. Journal of the Korean Society for Precision Engineering, 24(5), 7-13.

Jeon, Y.J., Kim, S.H., Yoon, K.T., Heo, Y.M., Lee, T.G., 2014. Indirect Prediction of Surface Damage for a Press Die with Wear Characteristics and Finite Element Stamping Analysis. 
Transactions of Materials Processing, 23(1), 29-34.

Kim, B.C., Yoon, S.H., Lee, D.G., 2011. Pressure Resistance of the Corrugated Stainless Steel Membranes of LNG Carriers. Ocean Engineering, 38, 592-608.

Kim, H.S., Chun, M.S., Lee, J.M., Kim, M.H., 2013. A Comparative Evaluation of Fatigue and Fracture Characteristics of Structural Components of Liquefied Natural Gas Carrier Insulation System. Journal of Pressure Vessel Technology, 135(2), 021405.

Kim, M.H., Lee, S.M., Lee, J.M., Noh, B.J., Kim, W.S., 2010. Fatigue Strength Assessment of MARK-III Type LNG Cargo Containment System. Ocean Engineering, 37, 1243-1252.

Lee, S.C., Kim, J.H., Kim, H.D., Choi, G.S., Amanov, A., Pyun, Y.S., 2015. Changes in Mechanical Properties of WC-Co by Ultrasonic Nanocrystal Surface Modification Technique. Journal of The Korean Society of Tribologists and Lubrication Engineers, 31(4), 157-162.
Pyun, Y.S., Suh, C.M., Yamaguchi, T., Im, J.S., Kim, J.H., Amanov, A., Park, J.H., 2012. Fatigue Characteristics of SAE52100 Steel via Ultrasonic Nanocrystal Surface Modification Technology. Journal of Nanoscience and Nanotechnology, 12, 6089-6095.

Suh, C.M., Nahm, S.H., Kim, J.H., Pyun, Y.S., 2016. A Study on the VHCF Fatigue Behaviors of Hydrogen Attacked Inconel 718 Alloy. Transactions of the Korean Society of Mechanical Engineers A, 40(7), 637-646.

Suh, C.M., Song, G.H., Suh, M.S., Pyoun, Y.S., 2007. Fatigue and Mechanical Characteristics of Nanostructured Tool Steel by Ultrasonic Cold Forging Technology. Materials Science and Engineering: A, 443(1-2), 101-106.

Yu, Y.H., Kim, B.G., Lee, D.G., 2013. Cryogenic Reliability of the Sandwich Insulation Board for LNG Ship. Composite Structures, 95, 547-556. 